\title{
IAMJ
}

INTERNATIONAL

AYURVEDIC

MEDICAL JOURNAL

\section{CRITICAL STUDY OF ABHYANGA W.S.R. TO COSMETIC EFFECT: A REVIEW}

\author{
$\underline{\text { Priyanka Bangre }}^{* 1}$, Archana Belge $^{2}$ \\ ${ }^{1}$ Final year P.G. Scholar, ${ }^{2}$ Professor, \\ Department of Swasthavritta, Shree Ayurveda Mahavidyalaya, Nagpur, Maharashtra, India
}

Corresponding Author: priyankakarande182@gmail.com

https://doi.org/10.46607/iamj4008102020

(Published online: October 2020)

Open Access

(C) International Ayurvedic Medical Journal, India 2020

Article Received: 20/09/2020 - Peer Reviewed: 29/09/2020 - Accepted for Publication: 04/10/2020

(A) Check for updates

\section{ABSTRACT}

Introduction- Ayurveda is the ancient science of complete health. Abhyanga is the essential part of Dincharya advised for overall health. In today's developed era, maintaining cosmetic health naturally, is the need. In Dincharya, Acharyas have explained Abhyanga for Healthy, beautiful skin and hair. Abhyanga not only prevents diseases but it is useful to maintain and restore cosmetic wellness also. In this article a thorough review on cosmetic benefits of Abhyanga, Shirobhyanga \& Padabhyanga, their procedures, mode of action is explained with the help of various classical texts like Charak Samhita, Sushrut Samhita etc. Relevant articles were analyzed \& reviewed for deeper understanding about Abhyanga. Discussion: Twacha is Aashrayasthan of Bhrajak Pitta. Application of Snehan dravyas for Abhyanga leads to its Pachana by Bhrajak Pitta. Health of skin can be improved by proper action of Bhrajak Pitta. Lymphatic system runs superficially under the skin \& thus Abhyanga helps in removal of lymphatic waste \& metabolic waste. Conclusion - Abhyanga is beneficial for cosmetic purpose. It makes skin healthy, soft and moisturized. It delays signs of aging. Shirobhyanga makes hair beautiful and lustrous and $\mathrm{Pa}$ dabhyanga makes feet beautiful and healthy.

Keywords- Abhyanga, Cosmetology, Padabhyanga, Shirobhyanga, Taila 


\section{INTRODUCTION}

Ayurveda is the traditional health care system. It not only deals with health of a person, but it teaches a complete way of life. Ayurveda deals with internal beauty (health) as well as external beauty and they both are closely related to each other. In today's modern lifestyle and practices external beauty plays a vital role and hence cosmetology is the emerging branch. Cosmetology is the branch which helps to alter the external appearance of a person \& modification of beauty. Cosmetology helps in developing an outwardly pleasant and attractive personality and thus helpful in achievement (punya), longevity with good health (Ayushya \& Arogyam) and happiness (Anandam). ${ }^{1}$ Cosmetology covers beauty of a whole body, especially beauty of a skin, complexion, healthy and lustrous hair, foot care etc. Skin not only covers our body, but it holds our emotions together. In Dincharya Acharyas have explained Abhyanga for healthy and beautiful skin \& hair. Abhyanga covers whole body massage for the benefits of skin, Shirobhyanga for maintenance of healthy hair and Padabhyanga for foot care. Daily practice of Abhyanga delays ageing, cures tiredness and Vata disorders, improves vision \& complexion and provides nourishment to body, increases longevity, makes skin lustrous and gives strength. ${ }^{2}$ In modern era Abhyanga is correlated with massage, but it's a broad term. Massage is particularly based on techniques of systemic rubbing, while Abhyanga is specially a massage with oil or unctuous substance. $A b$ hyanga provides a passive form of exercise even for those who cannot perform active physical exercise. Abhyanga means application of oil, ghee or any snigdha dravyas to the skin followed by massage in specific directions. Abhyanga should be done with Lukewarm oil. It should be done in the direction of hair (anulom gati) for proper absorption of oil. At joint it should be done in circular motion. ${ }^{3}$

\section{Effect of Abhyanga on Skin}

Beautiful skin gives pleasure and boosts up the confidence to some extent. Healthy skin is vital for our survival both, emotionally and physically. Vata dosha dominates the tactile sensory organ and this sensory organ is lodged in the skin. ${ }^{4}$ Vata dosha causes various disorders of skin. When Vayu is aggravated in the skin it causes Rukshata (dryness), Twaksphutan (cracking), and Karshnya (black coloration of skin). It also causes stretching and redness of the skin. ${ }^{5} \mathrm{Ab}$ hyanga is best for aggravated Vata dosha in the skin. ${ }^{6}$ Commonly Abhyanga is done with Snehan dravyas. Snehan dravyas are having opposite properties of Vata dosha that is Snigdh, Guru, Sheet, Mrudu Guna. Abhyanga done to the skin improves texture of skin, prevents wrinkles \& skin diseases like acne, gives strength to the face muscles and cheeks. Abhyanga improves blood circulation of the skin. The oxygen caring capacity of blood increases by doing $A b$ hyanga. Abhyanga improves the skin by enhancing the functions of sebaceous \& sweat glands. Abhyanga done with Kumkumadi taila, Eladi taila enhances complexion and make skin smooth and glowing. ${ }^{7}$ According to Acharya Sushrut Abhyanga provides a glossy softness to the skin, inhibits aggravation of Vata \& Kapha dosha. ${ }^{8}$ During winter season (Hemant and Shishir Ritu), atmospheric temperature is low and weather is cold. Due to this, blood vessels below the skin get constricted, less amount of blood flow to the surface of the skin \& complexion becomes dull. So, if regular Abhyanga is done then it will help to keep skin moisturized \& healthy. ${ }^{9}$ In old age, there is diminution of all Saptadhatu and dominance of Vata dosha. ${ }^{10}$ With the increase in age, skin related changes are most prominently noticeable. It includes wrinkles, sagging skin, outer layer of skin becomes thin. Changes in connective tissues reduces strength of skin and elasticity. Sebaceous glands functions become low \& it produces less oil. Abhyanga is said to be $j a$ rahar and it delays aging and thus it is useful in age related changes. ${ }^{11}$ In Abhyanga oil is used and the skin is relatively permeable to fat soluble substances. The oil molecules pass through dermis into the capillaries and into blood stream. The oil is also absorbed through hair follicle and sweat ducts. 
Table 1: Cosmetic benefits of different oils used for Abhyanga ${ }^{12,13,14}$

\begin{tabular}{|l|l|}
\hline Oils for Abhyanga & Cosmetic benefits \\
\hline sesame oil & $\begin{array}{l}\text { It acts as an antioxidant as it contains vitamin E and penetrates skin easily. It has best Vatshamak } \\
\text { property and hence used in dryness, cracking \& black coloration of skin. It enhances complexion and } \\
\text { makes healthy skin. }\end{array}$ \\
\hline Coconut Oil & $\begin{array}{l}\text { It is an effective moisturizer for all skin types. Prevents dryness \& flacking of skin, delays appearance } \\
\text { of wrinkles and sagging of skin. Helps in treating various skin problems \& prevents premature aging. }\end{array}$ \\
\hline Olive oil & $\begin{array}{l}\text { It prevents signs of photo aging \& sun damage. It has anti-aging properties. It acts as an antioxidant, } \\
\text { moisturizer and repairs cracked heels. Useful to cure brittle nails. }\end{array}$ \\
\hline
\end{tabular}

Effect of Shiroabhyanga: Application and Mardan of Taila to the Shirah Pradesh (head) is called Shirobhyanga. In Ayurveda, much importance is given to the Shirobhyanga. It is mentioned that if whole body massage is not possible everyday then at least one should massage to Shir (head), Shravan (Ear), \& Pada (foot sole) on daily basis. ${ }^{15}$

Procedure - Shirobhyanga should be done with cold or lukewarm oil, because head is the place of all senses $\&$ it is the most vital part of body. Shirobhyanga should be done for at least 400 Matra kal $(127 \mathrm{sec})$. At first, one should do massage to left and right parietal region and then to frontal, vertex \& occipital regions. One should massage gently to the scalp with the fingertips. ${ }^{16}$

\section{Cosmetic Benefits}

- Ayurveda considers hair as a byproduct of bone. The tissues which are responsible for formation of bones are also responsible for hair growth. When massage is done to the scalp heat is generated \& blood vessels get dilated, thus blood circulation towards it increases \& thus improves health of hair and scalp.

- One who does Shirobhyanga daily, gets the benefits of preventing hair fall \& graying of hair. It gives strength to scalp, strengthens hair roots \&makes the hair black \& long. Daily massage to the head make facial skin soft $\&$ provides luster to face. ${ }^{17}$

- Shirobhyanga softens the hair \& increases density. ${ }^{18}$ It is indicated in dry scalp \& it stops itching of scalp. ${ }^{19}$

- The skin, hair, horn \& bones of quadruped animals is burnt $\&$ reduced to ash and it is mixed in the oil. After application of this medicated oil fresh skin is developed over the ulcer \& natural hair grows at that site. ${ }^{20}$

Effect of Padabhyanga: Padabhyanga means Mardan with oil or ghee to the sole. It is an effective procedure. It is very simple process and requires less time $\&$ equipment. The foot and particularly sole contain specific points where the nerve endings relating to various body organs congregate.

Procedure- Padabhyanga can be done anytime but its effectiveness increases when it is done at bedtime. First Feet should be washed with warm water before massaging. Any medicated oil is best but in summer season Tila Taila and in winter season Mustard oil should be used. Massage should be done in downward direction (from ankle to toe). At joint circular movement should be done. It should be done for at least 10 to 15 minutes or till warmth is produced.

Cosmetic Benefits: Padabhyanga prevents and cures dryness, stiffness \& roughness of feet. It makes smooth skin and makes feet attractive and provides strength to the feet. ${ }^{21}$ so it is beneficial for cracked heels \& dryness of feet. Having low eyesight is the stigma on a beautiful face but Padabhyanga is said to be Drushtiprasadkrut means has a great role in improving eyesight, pleasantness of vision, \& eye health. Regular Padabhyanga soothes the feet, skin gets rejuvenated and begins to glow.

Mode of action of Abhyanga: Abhyanga directly effects on epidermis and influence keratinocytes for their protective quality and also to melanocytes which are responsible for color \& complexion of the skin. Under the epidermis lies dermis which contains mast cells, fibroblast and histocytes. Mast cells produce histamines. Histamines are the mediator of skin aller- 
gies. Abhyanga may have direct mast cell stabilizing effect \& mast cell cleansing effect which can be helpful in curing skin allergies \& urticaria.

Abhyanga directly affects mast cell, keratocyte, melanocytes and fibroblast. Thus, leads to cytostabilising effect on different cells and their functions. ${ }^{22}$ Hence Abhyanga makes healthy skin \& improves color and complexion. It also maintains elasticity of skin.

Water is the major component for keeping skin healthy and moisturized. Water originates in the deeper epidermis layer and comes upward to hydrates cells in the stratum corneum of skin and get evaporated. Abhyanga inhibits trans epidermal water loss, restoring the lipid barrier and amino lipid of the skin. ${ }^{23}$

Oil used for Abhyanga reaches up to different Dhatus when massaged for certain period of time. Thus it reaches up to the skin when massage is done for 400 Matra and removes disorders of skin, moisturizes it and makes healthy skin. When softness is induced in skin, it becomes lustrous, attains complexion \& color. An oily and unctuous skin prevents body from exposure of heat and dust also. Dust particles which are deposited are get cleaned by physical pressure applied during Abhyanga.

According to Acharya Sushruta, Abhyanga tend to dilate the orifices of the ducts and increases the temperature of the skin. Abhyanga improves the complexion and gives a lovely appearance, cleanliness, beauty and flexibility. Friction pacifies Vata, cures itches, rashes \& eruptions. ${ }^{24}$

\section{Contraindication of Abhyanga}

1. Abhyaanga is contraindicated in Kaphaj or Kapha dominant diseases.

2. After taking Vaman, Virechana or Basti.

3. Patients with Samavastha of Doshas, Santarpan Janya Vyadhi and Agnimandya.

4. In Ajirna and Taruna Jwara, Netra roga, Karna roga, Atisara, Aadhman, Peenasa, Agnimandya.

5. After Snana, Vyayama, Divaswapa, Vegdharana, Prajagrana, Sheet Vayu Sevana.

6. Immediately after consumption of food and after taking Ruksha and Abhishyandi Aahar.

\section{DISCUSSION}

In today's globalized and industrialized era, increase in stress, anxiety and pollution decreases the quality of health with increase in skin related problems. On the other hand, awareness of people for their look \& beauty is the current demand. Daily practice of Abhyanga is the key for this problem.

Bhrajak Pitta which is located in the skin is responsible for color \& luster of the skin. Normal \& abnormal complexion of skin depends upon the characteristics of Pitta Dosha. When Abhyanga is done, the oil applied to the skin is digested by the Bhrajak Pitta. So, the health of skin can be improved only after the proper action of Bhrajak Pitta. Bhrajak Pitta can be correlated with enzyme tyrosinase, which is responsible for melanin formation in the skin. Bhrajak Pitta and enzyme tyrosinase both are responsible for normal color of the body. Daily practice of Abhyanga improves blood circulation and enhances the natural function of the skin. Due to Abhyanga dilatation of superficial blood vessels takes place and increases the rate of blood flow. Lymphatic system runs superficially under the skin, thus ultimately Abhyanga helps in removal of lymphatic fluid and metabolic waste.

Due to Abhyanga, production of skin nurturing sebum is increased which is natural lubricant. It protects, cools, calms and maintains youthful properties of skin.

\section{CONCLUSION}

Abhyanga is economical and highly effective therapy which one should practice in daily routine. Abhyanga is having multiple health benefits including cosmetic purpose. Daily practice of Abhyanga makes lustrous and soft skin. Even during environmental challenges for dryness and cracking, it hydrates and lubricates the skin tissues. Daily Abhyanga strengthens skin and improves beauty. Onset of ageing decreases due to daily practice of Abhyanga. Daily practice of Shiroabhyanga prevents hair fall, graying of hair, gives strength to scalp, makes the hair black \& long. $\mathrm{Pa}$ dabhyanga prevents and cures dryness, roughness $\&$ stiffness of foot. It improves eyesight \& sleep related disorders. 


\section{REFERENCES}

1. Yasmine S. Ancient concept of cosmetology in Ayurveda, World journal of Pharmaceutical Research. Volume 6, issue 1, p.n. 241-252

2. Dr. Bramhananda Tripathi, Vagbhat, Ashtanghrudyam, Chaukhamba Sanskrit Pratishthan Prakashan, Delhi 2009 Sutrasthan $2 / 7$ p. 30

3. Vaidya Yadavji Trikamji Aacharya, Sushrut Samhita with Nibandhasangrah commentary, Chaukhamba Surbharti Prakashan, Varanasi. Chikitsasthan 24/30, edi. 2012.

4. Vaidya Yadavji Trikamji Aacharya, Agnivesh Charak Samhita with Aturved Deepika commentary, Chaukhamba Surbharti Prakashan, Varanasi. Sutrasthan 5/87

5. Vaidya Yadavji Trikamji Aacharya, Agnivesh Charak Samhita with Aturved Deepika commentary, Chaukhamba Surbharti Prakashan, Varanasi. Chikitsasthan $28 / 92$

6. Vaidya Yadavji Trikamji Aacharya, Agnivesh Charak Samhita with Aturved Deepika commentary, Chaukhamba Surbharti Prakashan, Varanasi. Sutrasthan 5/87

7. Dr. Ravikant Prajapati, Dr Mangalagauri Rao, Derma care through Ayurveda, European Journal of Pharmaceutical And medical Research 2017, 4(1), p. 277-283

8. Vaidya Yadavji Trikamji Aacharya, Sushrut Samhita with Nibandhasangrah commentary, Chaukhamba Surbharti Prakashan, Varanasi. Chikitsasthan 24/30, edi. 2012.

9. Dr. Ravikant Prajapati, Dr Mangalagauri Rao, Derma care through Ayurveda, European Journal of Pharmaceutical And medical Research 2017, 4(1), p. 277-283

10. Vaidya Yadavji Trikamji Aacharya, Agnivesh Charak Samhita with Aturved Deepika commentary, Chaukhamba Surbharti Prakashan, Varanasi. Vimansthan $8 / 22$.

11. Dr. Bramhananda Tripathi, Vagbhat, Ashtanghrudyam, Chaukhamba Sanskrit Pratishthan Prakashan, Delhi 2009 Sutrasthan $3 / 6$

12. Dr. Pravin Jawanjal, Tila tail: A review, World Journal of Pharmaceutical and Medical Research, 2018 4(10), p. $76-78$

13. G.S. Wala, P.K. Kapadiya, Medical Benefits of Coconut Oil, International Journal Of life science Research, 2014 Volume 2, Issue 4, p. 124-126

14. https://www.mapsofindia.com/my-india/health/18benefits-using-olive-oil-for-skin-health-and-hair
15. Dr. Bramhananda Tripathi, Vagbhat, Ashtanghrudyam, Chaukhamba Sanskrit Pratishthan Prakashan, Delhi 2009 Sutrasthan $2 / 8$ p. 30

16. V.k.agnihotri, Vijay Kumar, Richa Sharma, Therapeutic Significance of Shirobhyanga: A Review International Journal Of Research Ayurveda Pharm 6(6), 2015

17. Vaidya Yadavji Trikamji Aacharya, Agnivesh Charak Samhita with Aturved Deepika comentory, Chaukhamba Surbharti Prakashan, Varanasi. Sutrasthan 5/81

18. Vaidya Yadavji Trikamji Aacharya, Sushrut Samhita with Nibandhasangrah commentary, Chaukhamba Surbharti Prakashan, Varanasi. Chikitsasthan 24/25-26, edi. 2012

19. Dr. Bramhananda Tripathi, Vagbhat, Ashtanghrudyam, Chaukhamba Sanskrit Pratishthan Prakashan, Delhi 2009 Sutrasthan 35/16

20. Vaidya Yadavji Trikamji Aacharya, Agnivesh Charak Samhita with Aturved Deepika comentory, Chaukhamba Surbharti Prakashan, Varanasi. Chikitsasthan 25/18

21. Vaidya Yadavji Trikamji Aacharya, Agnivesh Charak Samhita with Aturved Deepika comentory, Chaukhamba Surbharti Prakashan, Varanasi. Sutrasthan 5/90

22. Vardhan Swati, Gupta Lokesh, Suman Lata, Akshara, Effect of Abhyanga, massage \& swedan On Components Of skin, International Aurvedic Medical journal, Volume 6, Issue 5, 2018 p. 1042-1045

23. Jayram Hazra, Ashok Kumar Panda, Concept of Beauty and Ayurveda Medicine, Clinical \& Experimental Dermatology Research Volume 4, Issue 3, 2013

24. Vaidya Yadavji Trikamji Aacharya, Sushrut Samhita with Nibandhasangrah Commentary, Chaukhamba Surbharti Prakashan, Varanasi. Chikitsasthan 24/29, edi. 2012.

\section{Source of Support: Nil Conflict of Interest: None Declared}

How to cite this URL: Priyanka Bangre \& Archana Belge: Effect Of Abhyanga W.S.R. To Cosmetology: A Review. International Ayurvedic Medical Journal \{online\} 2020 \{cited October, 2020\} Available from: http://www.iamj.in/posts/images/upload/4824_4828.pdf 